\title{
Properties of Calcium-Barium Titanate Dielectrics
}

\author{
By Elmer N. Bunting, George R. Shelton, and Ansel S. Creamer
}

\begin{abstract}
Dielectrics having compositions in the system $3 \mathrm{CaO}: \mathrm{TiO}_{2}-\mathrm{BaTiO}_{3}-\mathrm{TiO}_{2}$ were matured at $1,260^{\circ}$ to $1,500^{\circ} \mathrm{C}$. Data are given for the compositions, heat-treatments, absorption, shrinkage, and for $K$, the dielectric constant, and $Q$, the reciprocal of the power factor, at $25^{\circ} \mathrm{C}$ for frequencies of 50,1,000 and 20,000 kilocycles per second and for 3,000 megacycles per second when $K$ is not greater than 50 . Values of $K$ were also determined at 1 megacycle per second for various temperatures from $-60^{\circ}$ to $+85^{\circ} \mathrm{C}$. Lowest values of $Q$ (and highest of $K$ ) were associated with specimens of high baria content. Linear thermal expansion $\left(25^{\circ}\right.$ to $\left.700^{\circ} \mathrm{C}\right)$ ranged from 0.65 to 0.87 percent. The specimens of some compositions were unstable and changed in $K$ and $Q$ values with time.
\end{abstract}

\section{Introduction}

This paper is the third of a series dealing with ceramic dielectrics composed of titanium dioxide and the oxides of the alkaline earth elements. A study of these titanate systems previously reported $[1,2]^{1}$ revealed dielectrics of diverse properties that find application in the fields of electronic instrumentation, particularly where the space factor is important, as in hearing aids and other special circuits. These dielectrics are also valuable for the production of capacitors for use at temperatures above $150^{\circ} \mathrm{C}$, where paper and electrolytic capacitors do not function satisfactorily.

A rather limited amount of information has been published by others $[3,4]$ on the electrical properties of the calcium-barium titanates. However, it is desirable to investigate these materials for a wide range in composition so that a more complete knowledge of their properties will be available. Because the temperature coefficient of the dielectric constant for calcium titanate was known to be negative, it was expected that many of the calcium-barium titanate dielectrics might have a negative coefficient. Also, the low electrical-loss character of calcium titanate indicated that a large portion of the field in this system would probably behave similarly.

\footnotetext{
${ }^{1}$ Figures in brackets indicate the literature references at the end of this paper.
}

\section{Preparation of Dielectrics and Methods of Test}

Dielectrics having the compositions shown in figure 1 were prepared from reagent quality carbonates of calcium and barium and the commercial grade of titania (grade TMO) used in the preparation of the other alkaline earth titanate dielectrics $[1,2]$. A chemically pure grade of titania $(99.9 \%)$ was used in the preparation of a few specimens for comparison purposes. The methods of preparing these dielectrics and of determining

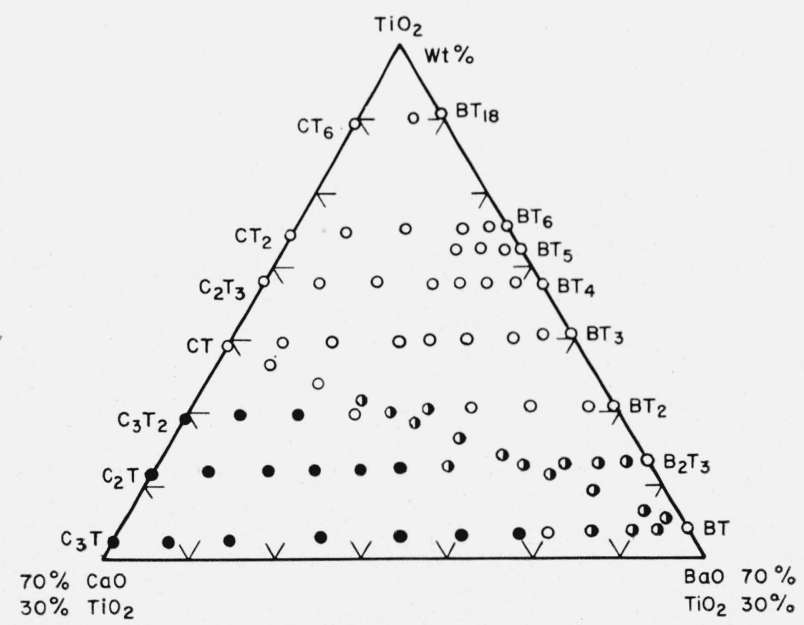

Figure 1. Ternary diagram for system $\mathrm{CaO}-\mathrm{BaO}-\mathrm{TiO}_{2}$ showing compositions studied.

$\mathrm{B}=\mathrm{BaO} ; \mathrm{C}=\mathrm{CaO} ; \mathrm{T}=\mathrm{TiO}_{2} ;$ thus, $\mathrm{B}_{2} \mathrm{~T}_{3}=2 \mathrm{BaO}: 3 \mathrm{TiO}_{2}$. , Decrease in $K$ and $Q$ with time; $\mathbf{O}$, decrease in $K$ and increase in $Q$ with time; $\bigcirc$, stable. 
their properties have been previously described $[1,2]$.

\section{Results and Discussion}

In table 1, data are given for the composition, heat-treatment, absorption, shrinkage, dielectric constant $K$, and reciprocal of the power factor, $Q$, of the matured specimens. The data for a given composition are considered to be the most representative among those obtained from measurements of 3 to 11 test specimens.

TABLE 1. Composition, heat treatment, absorption, shrinkage, dielectric constant $K$, and $Q$ of bodies in the system $3 \mathrm{CaO}: \mathrm{TiO}_{2}-\mathrm{BaTiO}_{3}-\mathrm{TiO}_{2}$

\begin{tabular}{|c|c|c|c|c|c|c|c|c|c|c|c|c|c|c|c|c|c|c|c|}
\hline \multirow{3}{*}{$\begin{array}{c}\text { Specimen } \\
\text { designation }\end{array}$} & \multirow{3}{*}{\multicolumn{2}{|c|}{$\begin{array}{c}\text { Proportion of } \\
\text { end members } \\
\text { of join, weight } \\
\text { percent }\end{array}$}} & \multicolumn{3}{|c|}{$\begin{array}{l}\text { Composition } \\
\text { weight }\end{array}$} & \multicolumn{4}{|c|}{ Heat treatment } & \multirow{3}{*}{$\begin{array}{l}\text { Ab- } \\
\text { sorp- } \\
\text { tion }\end{array}$} & \multirow{3}{*}{$\begin{array}{l}\text { Shrink- } \\
\text { age }\end{array}$} & \multicolumn{4}{|c|}{$\begin{array}{l}\text { Dielectric constant } K \text { at } \\
25^{\circ} \mathrm{C} \text { and }-\end{array}$} & \multicolumn{4}{|c|}{$\begin{array}{l}\text { Reciprocal, } Q \text {, of power } \\
\text { factor at } 25^{\circ} \mathrm{C} \text { and- }\end{array}$} \\
\hline & & & \multirow[b]{2}{*}{$\mathrm{BaO}$} & \multirow[b]{2}{*}{$\mathrm{CaO}$} & \multirow[b]{2}{*}{$\mathrm{TiO}_{2}$} & \multicolumn{2}{|c|}{ No. 1} & \multicolumn{2}{|c|}{ No. 2} & & & \multirow[b]{2}{*}{$\begin{array}{c}50 \\
\mathrm{kc} / \mathrm{s}\end{array}$} & \multirow[b]{2}{*}{$\begin{array}{l}1,000 \\
\mathrm{kc} / \mathrm{s}\end{array}$} & \multirow[b]{2}{*}{$\begin{array}{c}20 \\
\mathrm{mc} / \mathrm{s}\end{array}$} & \multirow[b]{2}{*}{$\begin{array}{l}3,000 \\
\mathrm{mc} / \mathrm{s}\end{array}$} & \multirow[b]{2}{*}{$\begin{array}{c}50 \\
\mathrm{kc} / \mathrm{s}\end{array}$} & \multirow[b]{2}{*}{$\begin{array}{l}1,000 \\
\mathrm{kc} / \mathrm{s}\end{array}$} & \multirow[b]{2}{*}{$\begin{array}{c}20 \\
\mathrm{mc} / \mathrm{s}\end{array}$} & \\
\hline & & & & & & $\begin{array}{l}\text { Tem- } \\
\text { per- } \\
\text { ature }\end{array}$ & Time & $\begin{array}{l}\text { Tem- } \\
\text { per- } \\
\text { ature }\end{array}$ & Time & & & & & & & & & & $\begin{array}{l}3,000 \\
\mathrm{mc} / \mathrm{s}\end{array}$ \\
\hline & $\begin{array}{l}\mathrm{CaO}: 6 \\
\mathrm{BaO}: 1\end{array}$ & & & & & & & & & & & & & & & & & & \\
\hline CT6 & 100 & $\ldots$ & $\begin{array}{c}\% \\
-2\end{array}$ & 10.5 & $\begin{array}{c}\% \\
89.5\end{array}$ & 1,100 & ${ }_{1}$ & 1,275 & 1 & $\begin{array}{c}\% \\
0.00\end{array}$ & $\begin{array}{l}\% \\
16.5\end{array}$ & 117 & 117 & 117 & & 1,700 & 1,900 & 2,400 & \\
\hline $18 \mathrm{BC} 6$ & 33 & 67 & 6.5 & 3.5 & 90 & 1,100 & 1 & 1,275 & 1 & .00 & 15.4 & 86 & 86 & 86 & & 600 & 1,000 & 1,800 & \\
\hline BT18 & 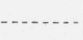 & 100 & 9.6 & $\ldots$ & 90.4 & 1,100 & 1 & 1,275 & 1 & .00 & 15.0 & 75 & 74 & 74 & $\cdots$ & 260 & 1,000 & 7,000 & \\
\hline & $\begin{array}{l}\mathrm{CaO}: \\
\mathrm{BaO}:\end{array}$ & & & & & & & & & & & & & & & & & & \\
\hline $\mathrm{C}$ T2 2 & 100 & & (n.... & 26.0 & 74.0 & 1,100 & 1 & 1,310 & 1 & .00 & 18.0 & 142 & 141 & 141 & & 1,900 & 1,200 & 1,800 & \\
\hline $6 \mathrm{BC} 2$ & 73 & 27 & 6.5 & 19.0 & 74.5 & 1,100 & 1 & 1,300 & 1 & .01 & 15. 6 & 107 & 107 & 107 & . & 700 & 500 & 1,000 & \\
\hline $6 \mathrm{BC} 5 \ldots$ & 43 & 57 & 13.0 & 12.0 & 75.0 & 1,100 & 1 & 1,310 & 1 & .00 & 17.1 & 84 & 83 & 83 & ... & 3,000 & 1, 400 & 2,700 & \\
\hline $6 \mathrm{BC} 8$ & 20 & 80 & 19.5 & 5.5 & 75.0 & 1,100 & 1 & 1,275 & 1 & .00 & 16.4 & 60 & 60 & 60 & $\ldots$ & 3,000 & 4,000 & 10,000 & - - \\
\hline $6 \mathrm{BC} 9$ & 5 & 95 & 23.0 & 1.5 & 75.5 & 1,100 & 1 & 1,275 & 1 & .00 & 15.9 & 49 & 49 & 49 & 48 & 2,000 & 10,000 & 10,000 & 960 \\
\hline BT6 & - & 100 & 24.3 & $\ldots$ & 75.7 & 1,100 & 1 & 1,275 & 1 & .00 & 13.7 & 46 & 45 & 44 & 39 & 85 & 400 & 2,200 & 490 \\
\hline & $\begin{aligned} 2 \mathrm{CaO} & \\
\mathrm{BaO} & \end{aligned}$ & & & & & & & & & & & & & & & & & & \\
\hline $\mathrm{C} 2 \mathrm{~T} 3$. & 100 & ... & .... & 31.9 & 68.1 & 1,100 & 1 & 1,310 & 1 & .00 & 17. 9 & 151 & 151 & 151 & & 2,000 & 1.000 & 1,600 & \\
\hline $\mathrm{BC} 22$ & 80 & 20 & 6.5 & 25.5 & 68.0 & 1,100 & 1 & 1,300 & 1 & .06 & 15.8 & 115 & 114 & 114 & & 700 & 300 & 700 & - \\
\hline $\mathrm{BC} 24$ & 60 & 40 & 13.0 & 19.1 & 67.9 & 1,100 & 1 & 1,295 & 1 & .01 & 18.3 & 88 & 87 & 87 & $\ldots$ & 1,000 & 1,000 & 1,500 & 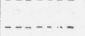 \\
\hline $\mathrm{BC} 26$ & 40 & 60 & 19.5 & 12.7 & 67.8 & 1,100 & 1 & 1,290 & 1 & .00 & 16.8 & 68 & 68 & 68 & - & 2,000 & 1,600 & 4,000 & - \\
\hline $\mathrm{BC} 27$ & 30 & 70 & 22. 7 & 9.6 & 67.7 & 1,100 & 1 & 1,290 & 1 & .00 & 17. 2 & 60 & 60 & 60 & $\ldots$ & 2,700 & 1,800 & 10,000 & - \\
\hline BC28 & 20 & 80 & 25.9 & 6.4 & 67.7 & 1,100 & 1 & 1,290 & 1 & .00 & 17. 2 & 51 & 51 & 50 & 47 & 2,600 & 4,000 & 10,000 & 940 \\
\hline BC29 ... & 10 & 90 & 29. 2 & 3.2 & 67.6 & 1,100 & 1 & 1,290 & 1 & .00 & 16. 9 & 44 & 44 & 43 & 42 & 2,700 & 1,900 & 5,000 & 2,100 \\
\hline BT4 & & 100 & 32.4 & $\ldots$ & 67.6 & 1,100 & 1 & 1,330 & 1 & .00 & 15.1 & 34 & 34 & 35 & 34 & 1,600 & 2,000 & 3,700 & 2,600 \\
\hline & $\begin{array}{l}\mathrm{CaO}: 1 \\
\mathrm{BaO}:\end{array}$ & & & & & & & & & & & & & & & & & & \\
\hline $5 \mathrm{BC} 8$ & 18 & 82 & 22.7 & 5.0 & 72.3 & 1,100 & 1 & 1,285 & 1 & .00 & 17. 0 & 56 & 56 & 56 & & 560 & 600 & 1,000 & \\
\hline $5 \mathrm{BC} 9$ & 9 & 91 & 25.2 & 2.5 & 72.3 & 1,100 & 1 & 1,285 & 1 & .00 & 16.0 & 49 & 49 & 49 & & 700 & 550 & 850 & \\
\hline $5 \mathrm{BC} 95$ & 5 & 95 & 26.5 & 1.2 & 72.3 & 1,100 & 1 & 1,285 & 1 & .00 & 15.1 & 45 & 45 & 45 & & 750 & 770 & 1,000 & \\
\hline BT5 & & 100 & 27.7 & $\ldots$ & 72.3 & 1. 100 & 1 & 1,325 & 1 & .04 & 12.0 & 39 & 37 & 37 & - & 1,500 & 2,300 & 1,300 & \\
\hline & $\begin{array}{l}\mathrm{CaO} \text {. } \\
\mathrm{BaO} \text { : }\end{array}$ & & & & & & & - & & & & & & & & & & & \\
\hline CT ... & 100 & -... & $\ldots$ & 41.2 & 58.8 & 1,100 & 1 & 1,400 & 1 & 0.01 & 16.7 & 143 & 143 & 143 & & 2,000 & 3,500 & 800 & \\
\hline $\mathrm{BC2}$ & 83 & 17 & 6.5 & 34.4 & 59.1 & 1,000 & 1 & 1,320 & 5 & a2. 65 & 18.3 & 115 & 112 & 109 & . & 20 & 59 & 225 & \\
\hline BC3 & 70 & 30 & 11. 7 & 28.9 & 59.4 & 1,000 & 1 & 1,320 & 5 & ^1. 62 & 19.4 & 112 & 110 & 107 & & 25 & 90 & 570 & \\
\hline BC5 & 50 & 50 & 19.5 & 20.6 & 59.9 & 1,000 & 1 & 1,275 & 2 & 0.00 & 19. 0 & 94 & 94 & 94 & -..... & 1,300 & 1,200 & 1,100 & $\ldots$ \\
\hline BC6 & 40 & 60 & 23.4 & 16.5 & 60.1 & 1,100 & 1 & 1, 290 & 1 & .04 & 16.6 & 82 & 82 & 81 & ...... & 600 & 1,400 & 2,800 & \\
\hline $\mathrm{BC7}$ & 30 & 70 & 27.3 & 12.4 & 60.3 & 1,100 & 1 & 1,290 & 1 & .00 & 17.0 & 72 & 72 & 71 & ....... & 1,600 & 2,400 & 4,000 & - . . \\
\hline BC8 & 17 & 83 & 32.4 & 7.0 & 60.6 & 1,100 & 1 & 1,290 & 1 & .00 & 17. 0 & 57 & 57 & 56 & -...... & 3,800 & 3,400 & 10,000 & - . \\
\hline $\mathrm{BC} 9$ & 10 & 90 & 35.1 & 4. 1 & 60.8 & 1,100 & 1 & 1,260 & 1 & .00 & 17. 7 & 52 & 52 & 51 & 50 & 2,400 & 3,600 & 10,000 & 1,240 \\
\hline BT3... & ... & 100 & 39.0 & $\ldots$ & 61.0 & 1,100 & 1 & 1,260 & 1 & .03 & 17. 4 & 44 & 44 & 43 & 42 & 650 & 720 & 800 & 460 \\
\hline
\end{tabular}


TABLE 1. Composition, heat treatment, absorption, shrinkage, dielectric constant $K$, and $Q$ of bodies in the system $3 \mathrm{CaO}: \mathrm{TiO}_{2}-\mathrm{BaTiO}_{3}-\mathrm{TiO}_{2}-$ Continued

\begin{tabular}{|c|c|c|c|c|c|c|c|c|c|c|c|c|c|c|c|c|c|c|c|}
\hline \multirow{3}{*}{$\begin{array}{c}\text { Specimen } \\
\text { designation }\end{array}$} & \multirow{3}{*}{\multicolumn{2}{|c|}{$\begin{array}{c}\text { Proportion of } \\
\text { end members } \\
\text { of join, weight } \\
\text { percent }\end{array}$}} & \multicolumn{3}{|c|}{$\begin{array}{l}\text { Composition } \\
\text { weight }\end{array}$} & \multicolumn{4}{|c|}{ Heat treatment } & \multirow{3}{*}{$\begin{array}{l}\text { Ab- } \\
\text { sorp- } \\
\text { tion }\end{array}$} & \multirow{3}{*}{$\begin{array}{l}\text { Shrink- } \\
\text { age }\end{array}$} & \multicolumn{4}{|c|}{$\begin{array}{c}\text { Dielectric constant } K \text { at } \\
25^{\circ} \mathrm{C} \text { and }-\end{array}$} & \multicolumn{4}{|c|}{$\begin{array}{l}\text { Reciprocal, } Q \text {, of power } \\
\text { factor at } 25^{\circ} \mathrm{C} \text { and- }\end{array}$} \\
\hline & & & \multirow[b]{2}{*}{$\mathrm{BaO}$} & \multirow[b]{2}{*}{$\mathrm{CaO}$} & \multirow[b]{2}{*}{$\mathrm{TiO}_{2}$} & \multicolumn{2}{|c|}{ No. 1} & No & . 2 & & & & & & & & & & \\
\hline & & & & & & $\begin{array}{l}\text { Tem- } \\
\text { per- } \\
\text { ature }\end{array}$ & Time & $\begin{array}{l}\text { Tem- } \\
\text { per- } \\
\text { ature }\end{array}$ & Time & & & $\begin{array}{c}50 \\
\mathrm{kc} / \mathrm{s}\end{array}$ & $\begin{array}{l}1,000 \\
\mathrm{kc} / \mathrm{s}\end{array}$ & $\begin{array}{c}20 \\
\mathrm{mc} / \mathrm{s}\end{array}$ & $\begin{array}{l}3,000 \\
\mathrm{mc} / \mathrm{s}\end{array}$ & $\begin{array}{c}50 \\
\mathrm{kc} / \mathrm{s}\end{array}$ & $\begin{array}{l}1,000 \\
\mathrm{kc} / \mathrm{s}\end{array}$ & $\begin{array}{c}20 \\
\mathrm{mc} / \mathrm{s}\end{array}$ & $\begin{array}{l}3,000 \\
\mathrm{mc} / \mathrm{s}\end{array}$ \\
\hline & $\begin{array}{r}\mathrm{CaT} \\
\mathrm{Ba}\end{array}$ & & & & & & $h r$ & & & & & & & & & & & & \\
\hline $\mathrm{CT}_{\text {. }}$ & 100 & $\cdots$ & $\ldots$ & 41. 2 & 58.8 & 1,100 & 1 & 1,400 & 1 & .01 & 16.7 & 143 & 143 & 143 & - & 2,000 & 3,500 & 800 & \\
\hline CB1 & 90 & 10 & 6.6 & 37.1 & 56.3 & 1,100 & 3 & 1,430 & 1 & .01 & 16.3 & 155 & 155 & 155 & & 6,400 & 3,800 & 1,900 & \\
\hline $\mathrm{CB} 2 \ldots$ & 80 & 20 & 13.1 & 33.0 & 53.9 & 1,100 & 3 & 1,430 & 1 & .01 & 15. 7 & 185 & 185 & 185 & & 2,300 & 2,100 & 1,200 & \\
\hline $\mathrm{CB} 3 \mathrm{~b}_{\ldots}$ & 70 & 30 & 19. 7 & 28.9 & 51.4 & 1,100 & 3 & 1,430 & 1 & .00 & 14. 3 & 220 & 220 & 220 & & 1,000 & 680 & 470 & \\
\hline $\mathrm{CB} 35 \mathrm{~b}$ & 65 & 35 & 23.2 & 26.8 & 50.0 & 1,245 & 1 & 1,400 & 1 & .05 & 13.1 & 240 & 240 & 240 & & 1,000 & 700 & 520 & \\
\hline $\mathrm{CB} 4 \mathrm{~b}_{-.}$ & 60 & 40 & 26.3 & 24.7 & 49.0 & 1,100 & 3 & 1,430 & 1 & .01 & 14.3 & 265 & 265 & 265 & & 780 & 480 & 280 & \\
\hline CB 5 b & 50 & 50 & 32.8 & 20.6 & 46.5 & 1,100 & 3 & 1,430 & 1 & .03 & 13.8 & 315 & 315 & 315 & & 600 & 390 & 190 & \\
\hline $\mathrm{CB} 6 \mathrm{~b}_{-}$ & 40 & 60 & 39.4 & 16.5 & 44.1 & 1,100 & 3 & 1,430 & 1 & .03 & 13.7 & 380 & 380 & 380 & & 440 & 310 & 175 & \\
\hline $\mathrm{CB} 64^{\mathrm{b}}$ & 36 & 64 & 42.0 & 15.0 & 43. 0 & 1,100 & 3 & 1,430 & 1 & .00 & 13.4 & 400 & 400 & 400 & & 460 & 270 & 130 & \\
\hline $\mathrm{CB} 7 \mathrm{~b}$ & 30 & 70 & 46. 0 & 12.4 & 41. 6 & 1,100 & 3 & 1,430 & 1 & .00 & 15. 6 & 440 & 440 & 430 & & 400 & 260 & 120 & \\
\hline $\mathrm{CB} 8 \mathrm{~b}$ & 20 & 80 & 52.5 & 8.3 & 39.2 & 1,100 & 3 & $\mathbf{1}, 430$ & 1 & .00 & 14. 6 & 540 & 540 & 530 & & 570 & 325 & 175 & \\
\hline CB9 b & 10 & 90 & 59.1 & 4.1 & 36.8 & 1,100 & 3 & 1,430 & 1 & .00 & 14.6 & 600 & 600 & 590 & & 240 & 160 & 95 & \\
\hline CB95 b . & 5 & 95 & 62.4 & 2. 1 & 35.5 & 1,100 & 3 & 1,430 & 1 & .02 & 14. 3 & 840 & 840 & 830 & & 130 & 120 & 80 & \\
\hline BT. & & 100 & 65.7 & ...... & 34.3 & 1,245 & 1 & 1,385 & 2 & .05 & 10.6 & 1,400 & 1,400 & 1,400 & & 100 & 130 & 70 & \\
\hline & $\begin{array}{r}3 \mathrm{CaO}: \\
\mathrm{BaO}:\end{array}$ & ${ }_{2},-$ & & & & & & & & & & & & & & & & & \\
\hline C3T2 & 100 & $\ldots$ & .... & 51.3 & 48. 7 & 1,245 & 1 & 1,500 & 1 & .02 & 15.1 & 55 & 55 & 55 & & 2,000 & 10,000 & 2,400 & \\
\hline BC321 ... & 87 & 13 & 6.5 & 44.5 & 49. 0 & 1,100 & 1 & 1,470 & 1 & .00 & 14.1 & 67 & 67 & 67 & & 2,000 & 3,000 & 2,000 & \\
\hline BC323 & 74 & 26 & 13.0 & 37.5 & 49.5 & J, 245 & 1 & 1,500 & 1 & .01 & 16.9 & 83 & 83 & 83 & & 1,500 & 1,600 & 1,900 & \\
\hline BC324 & 60 & 40 & 19.5 & 31.0 & 49.5 & 1,245 & 1 & 1,500 & 1 & .01 & 17.0 & 150 & 150 & 150 & & 1,600 & 1,600 & 1, 700 & \\
\hline BC325 & 53 & 47 & 23. 2 & 26.8 & 500 & 1,100 & 1 & 1,420 & 1 & .01 & 15.0 & 235 & 233 & 231 & & 500 & 350 & 200 & \\
\hline BC $326 \ldots$ & 43 & 57 & 28.0 & 22.0 & 50.0 & 1,000 & 1 & 1,275 & 5 & a. 48 & 18. 6 & 265 & 260 & 258 & & 61 & 65 & 60 & \\
\hline BC327 & 33 & 67 & 32.8 & 17.2 & 50.0 & 1,000 & 1 & 1,275 & 2 & a. 48 & 19.1 & 270 & 265 & 265 & & 60 & 65 & 45 & \\
\hline BC328 & 20 & 80 & 39.4 & 10.0 & 50.6 & 1,100 & 1 & 1,265 & 1 & .04 & 17.3 & 215 & 210 & 209 & & 80 & 65 & 43 & \\
\hline BC 329 & 6 & 94 & 46.0 & 3.0 & 51.0 & 1,100 & 1 & 1,265 & 1 & .00 & 15.5 & 185 & 180 & 175 & & 60 & 50 & 38 & \\
\hline BT2..... & . & 100 & 49.0 & -..... & 51.0 & 1,100 & 1 & 1,290 & 1 & .02 & 16.4 & 204 & 200 & 197 & & 100 & 70 & 35 & - \\
\hline . & $\begin{array}{l}2 \mathrm{CaO} \\
2 \mathrm{BaO}\end{array}$ & & & & & & & & & & & & & & & & & & \\
\hline $\mathrm{C} 2 \mathrm{~T}_{\ldots}$ & 100 & $\ldots$ & -... & 58.4 & 41.6 & 1,100 & 1 & 1,500 & $e_{1}$ & .01 & 18.3 & 40 & 40 & 40 & 40 & 2,700 & 5,000 & 1,700 & 360 \\
\hline $\mathrm{B} 2 \mathrm{C} 21$ & 89 & 11 & 6. 2 & 52.0 & 41.8 & 1,100 & 1 & 1,500 & 1 & .00 & 19.8 & 46 & 46 & 46 & 44 & 1,400 & 2,700 & 1,200 & 470 \\
\hline $\mathrm{B} 2 \mathrm{C} 22$ & 76 & 24 & 13. 2 & 44.6 & 42.1 & 1,100 & 1 & 1,500 & 1 & .06 & 18.0 & 46 & 46 & 46 & 45 & 1,800 & 3,300 & 1,200 & 520 \\
\hline $\mathrm{B} 2 \mathrm{C} 23 \ldots$ & 68 & 32 & 18.1 & 39.5 & 42.3 & 1,100 & 1 & 1,450 & 1 & .00 & 16.0 & 49 & 49 & 49 & & 1,400 & 2,100 & 2,000 & . \\
\hline $\mathrm{B} 2 \mathrm{C} 24 \ldots$ & 58 & 42 & 23.7 & 33.7 & 42.6 & 1,100 & 1 & 1,500 & 1 & .00 & 14.5 & 56 & 56 & 56 & & 900 & 1,400 & 1,800 & $\ldots$ \\
\hline $\mathrm{B} 2 \mathrm{C} 25 \ldots$ & 50 & 50 & 28.1 & 29.2 & 42.7 & 1,100 & 1 & 1,430 & 1 & .00 & 15.4 & 73 & 73 & 73 & ..... & 700 & 2,000 & 2,000 & |... \\
\hline $\mathrm{B} 2 \mathrm{C} 26 \mathrm{~b}$ & 40 & 60 & 33.7 & 23.3 & -43.0 & 1,100 & 1 & 1,500 & 1 & .01 & 14. 6 & 210 & 210 & 210 & $\ldots$ & 1,000 & 1,000 & 1,000 & - \\
\hline $\mathrm{B} 2 \mathrm{C} 28^{\mathrm{b}}$ & 17 & 83 & 46. 6 & 9.9 & 43.5 & 1,100 & 1 & 1,280 & 3 & a. 23 & 14.6 & 480 & 480 & 470 & & 67 & 55 & 35 & - \\
\hline $\mathrm{B} 2 \mathrm{C} 29^{\mathrm{b}}$ & 10 & 90 & 50.5 & 5.8 & 43.7 & 1,100 & 1 & 1,265 & 1 & .00 & 14. 6 & 520 & 515 & 500 & -... & 50 & 33 & 25 & -.... \\
\hline $\mathrm{B} 2 \mathrm{C} 295 \mathrm{~b}$ & 5 & 95 & 53.3 & 2. 9 & 43.8 & 1,100 & 1 & 1,265 & 1 & .00 & 15.5 & 580 & 570 & 550 & $\ldots$ & 40 & 27 & 20 & - . . . \\
\hline B2T3 & & 100 & 56.1 & -.... & 43.9 & 1,250 & 1 & 1,300 & 1 & .01 & 10.8 & 910 & 900 & 890 & -.... & 70 & 50 & 25 & $\ldots$ \\
\hline & $\begin{array}{r}3 \mathrm{CaO} \\
\mathrm{Ba} T\end{array}$ & & & & & & & & & & & & & & & & & & \\
\hline C3T & $\mathrm{i} 00$ & & .... & 67.8 & 32. 2 & 1,100 & 1 & 1,500 & 1 & .01 & 22.0 & 34 & 34 & 34 & 33 & 2,000 & 5,000 & 3,000 & 300 \\
\hline BC31 & 90 & 10 & 6.6 & 61.0 & 32.4 & 1,100 & 1 & 1,500 & 1 & .00 & 24.0 & 40 & 40 & 40 & 38 & 1,200 & 2,600 & 2,400 & 580 \\
\hline BC32 & 80 & 20 & 13.1 & 54.2 & 32.6 & $\mathrm{~J}, 100$ & 1 & 1,500 & 1 & .00 & 22.8 & 39 & 39 & 39 & 38 & 2,000 & 3,000 & 3,000 & 690 \\
\hline BC $33 \ldots$ & 64 & 36 & 23.6 & 43.4 & 33.0 & 1,100 & 1 & 1,500 & 1 & .00 & 18.8 & 37 & 37 & 37 & 37 & 1,400 & 4,000 & 6,000 & 430 \\
\hline BC $35 \ldots$ & 50 & 50 & 32.9 & 33.9 & 33.2 & 1,100 & 1 & 1,500 & 1 & .00 & 17. 5 & 36 & 36 & 36 & $\ldots$ & 1,400 & 4,000 & 6,000 & $\ldots$ \\
\hline BC $36 \ldots$ & 40 & 60 & 39.4 & 27.1 & 33.5 & 1,100 & 1 & 1,450 & 1 & .00 & 16.7 & 37 & 37 & 37 & 36 & 2,000 & 4,000 & 9,000 & 350 \\
\hline BC37_.... & 29 & 71 & 46.6 & 19. 7 & 33.7 & 1,100 & 1 & 1,470 & 1 & .00 & 15.8 & 37 & 37 & 36 & 38 & 1,400 & 2,000 & 5,000 & 370 \\
\hline BC375 ....... & 25 & 75 & 49.5 & 16.7 & 33.8 & 1,100 & 1 & 1,500 & 1 & .00 & 15.9 & 60 & 60 & 60 & $\mid \ldots-$ & 1,300 & 5,000 & 5,000 & - \\
\hline BC38.... & 16 & 84 & 55.0 & 11. 0 & 34.0 & 1,245 & 1 & 1,430 & 1 & .00 & 14. 6 & 640 & 630 & 620 & & 300 & 300 & 200 & -...... \\
\hline BC39 b & 10 & 90 & 59.1 & 6.8 & 34.1 & 1,245 & 1 & 1,410 & 1 & .00 & 13. 6 & 1,640 & 1,630 & 1,620 & & 170 & 190 & 110 & - \\
\hline BC395 b & 5 & 95 & 62.4 & 3.4 & 34.2 & 1,100 & 1 & 1,410 & 1 & .01 & 14.0 & 2,680 & 2,670 & 2,640 & - . . & 140 & 120 & 55 & - \\
\hline BT & & 100 & 6.5. 7 & $\ldots$. & 34.3 & 1. 245 & 1 & 1.385 & 2 & .05 & 10.6 & 1.400 & 1,400 & 1,400 & ... & 100 & 130 & 70 & $\ldots$. \\
\hline
\end{tabular}

a Not matured.

b $K$ and $Q$ values obtained after 6 months.

c Three heats at $1,500^{\circ} \mathrm{C}$ for $1 \mathrm{hr}$. 
The relation between the maturing temperature and the composition of the specimens is shown in figure 2. No attempt was made to determine in all cases the range of temperatures within which mature specimens could be produced, but it was noted that, in general, this range was about $10^{\circ} \mathrm{C}$. When the compositions were in the region of $\mathrm{CaO}: 2 \mathrm{TiO}_{2}{ }^{2}$, containing a few percent of $\mathrm{BaO}$, the maturing range was less than $10^{\circ} \mathrm{C}$. This region may be near a ternary eutectic. In another area two mixtures, designated $\mathrm{BC} 2$ and $\mathrm{BC} 3$, and three other mixtures (BC326, BC327, and $\mathrm{B} 2 \mathrm{C} 28$ ) did not yield mature specimens, despite many attempts with systematic variations in the duration and temperature of heat treatments. The lowest absorption obtained for these specimens was between 0.5 and 1.6 percent.

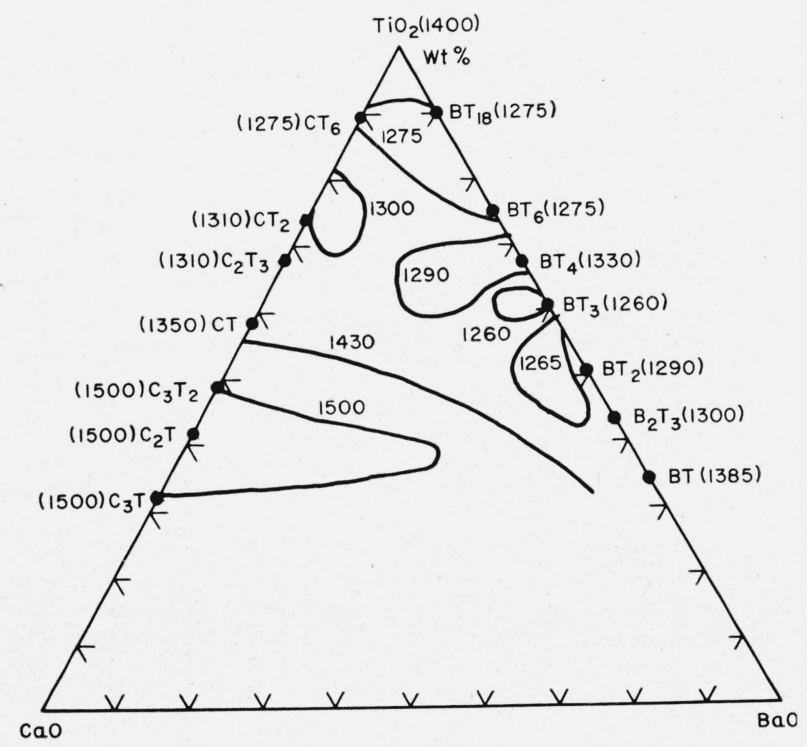

Figure 2. Approximate maturing temperature $\left({ }^{\circ} C\right)$ after calcining treatment.

$\mathrm{B}=\mathrm{BaO} ; \mathrm{C}=\mathrm{CaO} ; \mathrm{T}=\mathrm{TiO}_{2}$.

Small amounts of impurities have a pronounced effect on the maturing temperature of some preparations, particularly those representing a definite compound. If calcium titanate is prepared with titania containing 1.3 percent of impurities, the range in maturing temperature extends from $1,350^{\circ}$ to $1,400^{\circ} \mathrm{C}$. However, when less than a tenth of 1 percent of impurities is present, a maturing temperature of about $1,500^{\circ} \mathrm{C}$ is required.

\footnotetext{
2 A colon indicates that the composition may or may not be a compound. A known compound is represented by a single dot separating the oxide formulae, or by a single formula, as $\mathrm{CaTiO}_{3}$.
}

At $25^{\circ} \mathrm{C}$ the variations in $K$ and $Q$, with composition, measured at $1 \mathrm{mc} / \mathrm{s}$, are shown in figures 3 and 4, respectively. The ternary parts of these diagrams exhibit isodielectric-constant lines plotted from the data on $K$ and $Q$ given in table 1 . Underneath and to the right side of the ternary diagram, the values of $K$ (or $Q$ ) are plotted for the binary systems of $\mathrm{CaO}-\mathrm{TiO}_{2}$ and $\mathrm{BaO}-\mathrm{TiO}_{2}$. Systematically varying the compositions of the specimens affected the values of $K$ and $Q$, as given in table 1 .

In the $\mathrm{CaO}-\mathrm{TiO}_{2}$ system, the substitution of $\mathrm{CaO}$ for $\mathrm{TiO}_{2}$, up to about 41 percent of $\mathrm{CaO}$, raised the $K$ value from near 100 for $\mathrm{TiO}_{2}$ to about

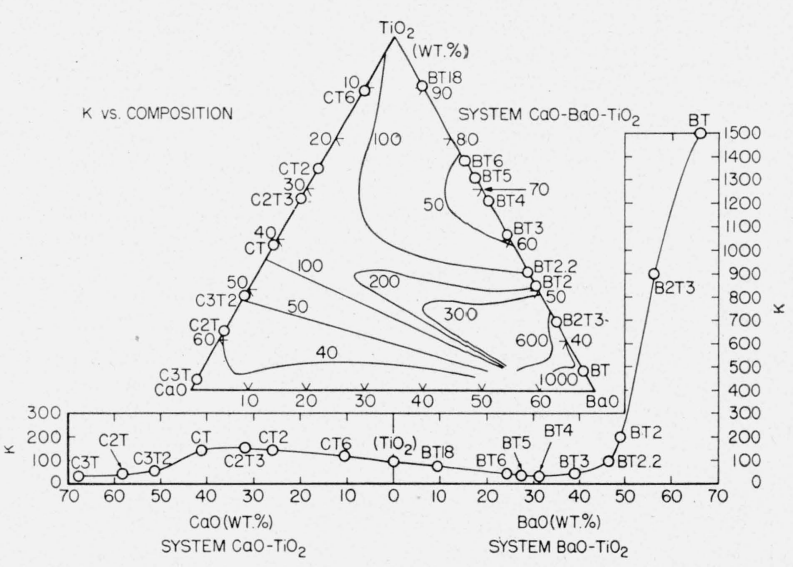

Figure 3. Dielectric constant, at $25^{\circ} \mathrm{C}$ and $1 \mathrm{mc} / \mathrm{s}$, with varying composition within the ternary system, $3 \mathrm{CaO}$ : $\mathrm{TiO}_{2}-\mathrm{BaTiO}_{3}-\mathrm{TiO}_{2}$, and the binary systems, $\mathrm{CaO}-\mathrm{TiO}_{2}$ and $\mathrm{BaO}-\mathrm{TiO}_{2}$.

$\mathrm{B}=\mathrm{BaO} ; \mathrm{C}=\mathrm{CaO} ; \mathrm{T}=\mathrm{TiO}_{2}$

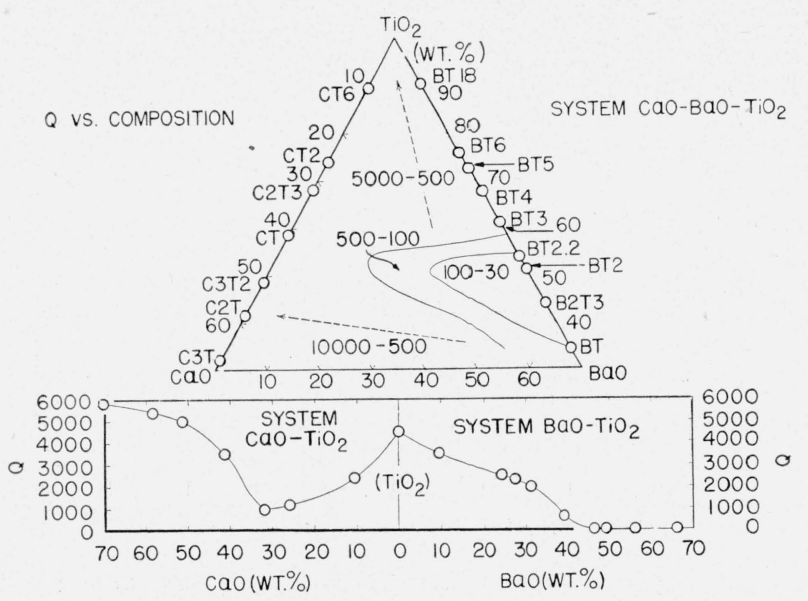

Figure 4. Q values, at $25^{\circ} \mathrm{C}$ and $1 \mathrm{mc} / \mathrm{s}$, with varying composition within the ternary system, $3 \mathrm{CaO}: \mathrm{TiO}_{2-}$ $\mathrm{BaTiO}_{3}-\mathrm{TiO}_{2}$, and the binary systems, $\mathrm{CaO}-\mathrm{TiO}_{2}$ and $\mathrm{BaO}-\mathrm{TiO}_{2}$.

$\mathrm{B}=\mathrm{BaO} ; \mathrm{C}=\mathrm{CaO} ; \mathrm{T}=\mathrm{TiO}_{2}$. 
140 for $\mathrm{CaTiO}_{3}$ (fig. 3). Higher values, up to 168, have been reported by others [4]. The different values obtained were probably due to variations in the crystal development as influenced by impurities and heat-treatment. ? values (fig. 4) were progressively lowered when $\mathrm{CaO}$ replaced $\mathrm{TiO}_{2}$ and became a minimum when the $\mathrm{CaO}$ content reached about 31 percent. Further additions of $\mathrm{CaO}$ increased the $Q$ values.

Within the ternary system for dielectrics having percentages of $\mathrm{TiO}_{2}$ greater than about 60 , the replacement of $\mathrm{BaO}$ by $\mathrm{CaO}$ increased the values of $K$ but did not greatly decrease those of $Q$, in contrast to the effect of replacing $\mathrm{BaO}$ by $\mathrm{MgO}$ [2]. However, for dielectrics having compositions on the join $\mathrm{CaTiO}_{3}-\mathrm{BaTiO}_{3}$, increasing the content of $\mathrm{CaTiO}_{3}$ resulted in a continuous decrease in $K$, from about 1,400 for $\mathrm{BaTiO}_{3}$ to near 140 for $\mathrm{CaTiO}_{3}$, and in an increase in $Q$, from 130 for $\mathrm{BaTiO}_{3}$ to 3,500 for $\mathrm{CaTiO}_{3}$, measured at $25^{\circ} \mathrm{C}$ and $1 \mathrm{mc} / \mathrm{s}$. For specimens having compositions along the join $3 \mathrm{CaO}: 2 \mathrm{TiO}_{2}-\mathrm{BaO}: 2 \mathrm{TiO}_{2}$, the initial substitution of $\mathrm{CaO}$ for $\mathrm{BaO}$ resulted in a decrease in $K$ from 200 to 180 and in $Q$ from 70 to 50 . Further increase in $\mathrm{CaO}$ content increased $K$ to a maximum of 265 at 33 percent of $3 \mathrm{CaO}: 2 \mathrm{TiO}_{2}$, followed by a decrease in $K$ to 55 for 100 percent of $3 \mathrm{CaO}: 2 \mathrm{TiO}_{2}$. $Q$ values were below 100 for specimens containing less than about 50 percent of $3 \mathrm{CaO}: 2 \mathrm{TiO}_{2}$ and above 200 at higher $\mathrm{CaO}$ content. Along the join $2 \mathrm{CaO}: \mathrm{TiO}_{2}-2 \mathrm{BaO}: 3 \mathrm{TiO}_{2}, K$ for the dielectrics was continuously reduced, as $\mathrm{CaO}$ replaced $\mathrm{BaO}$, from 900 for $2 \mathrm{BaO}: 3 \mathrm{TiO}_{2}$ to 40 for $2 \mathrm{CaO}: \mathrm{TiO}_{2}$. The $Q$ value, although less than 100 when the percentage of $2 \mathrm{CaO}: \mathrm{TiO}_{2}$ was 17 percent or less, was several hundred at higher $\mathrm{CaO}$ content. On the join $3 \mathrm{CaO}: \mathrm{TiO}_{2}-\mathrm{BaTiO}_{3}$, the replacement of $\mathrm{BaTiO}_{3}$ by 5 percent of $3 \mathrm{CaO}$ : $\mathrm{TiO}_{2}$ increased $K$ from 1,400 to 2,670 , but additional replacement to 10 percent of $3 \mathrm{CaO}: \mathrm{TiO}_{2}$ reduced $K$ to 1,630 . Further increase in the content of $3 \mathrm{CaO}: \mathrm{TiO}_{2}$ to 25 percent resulted in a rapid decrease in $K$ to a value of 60 . From 29 percent to 100 percent, $K$ remained near 40 . The $Q$ value was not over 300 from 0 to 16 percent of $3 \mathrm{CaO}$ : $\mathrm{TiO}_{2}$, but for higher percentages $Q$ ranged from 2,000 to 5,000 .

Certain specimens, indicated in figure 1 , were found to decrease in $K$ and increase in $Q$ with time after the final heat treatment. Similar behavior was noted and described for some of the titanate dielectrics previously studied [2]. Data showing the extent of these changes after storage for 6 months under room conditions are given in table 2 . Although the maximum decrease in $K$ for any specimen was less than 25 percent, the maximum increase in $Q$ was 225 percent. These changes appear only in the dielectrics containing less than about 50 percent of titania and more than about 25 percent of baria. In this region, the presence of the crystalline forms of $\mathrm{BaTiO}_{3}$, with some solid solution, might be expected, and changes in this crystalline structure may be associated with the instability of the specimens. The data in table 1 were obtained after the $K$ and $Q$ values had been stabilized by aging these specimens for 6 months.

TABLE 2.-Changes in $K$ and $Q$ of some specimens after 6 months of storage

[Measured at $1 \mathrm{mc} / \mathrm{s}$ and $25^{\circ} \mathrm{C}$ ]

\begin{tabular}{|c|c|c|c|c|c|c|}
\hline \multirow{2}{*}{ Specimen designation } & \multicolumn{3}{|c|}{ Dielectric constant, $K$} & \multicolumn{3}{|c|}{ Quality factor, $Q$} \\
\hline & $\begin{array}{c}\text { After } 1 \\
\text { day }\end{array}$ & $\begin{array}{l}\text { After } 6 \\
\text { months }\end{array}$ & Change & $\begin{array}{c}\text { After } 1 \\
\text { day }\end{array}$ & $\begin{array}{l}\text { After } 6 \\
\text { months }\end{array}$ & Change \\
\hline $\mathrm{CB} 3 \ldots$ & 228 & 217 & $\begin{array}{c}\% \\
-4.8\end{array}$ & 305 & 680 & $\begin{array}{c}\% \\
128\end{array}$ \\
\hline CB35 & 249 & 238 & -4.4 & 215 & 700 & 225 \\
\hline CB4 ... & 285 & 264 & -7.4 & 200 & 480 & 140 \\
\hline CB5 & 347 & 315 & -9.2 & 151 & 390 & 160 \\
\hline CB6... & 426 & 380 & -10.8 & 105 & 310 & 195 \\
\hline CB64 . & 464 & 401 & -13.6 & 94 & 270 & 187 \\
\hline CB7 $\ldots$ & 516 & 440 & -14.7 & 90 & 264 & 193 \\
\hline CB8 $\ldots$ & 657 & 542 & -17.5 & 102 & 325 & 219 \\
\hline CB9 & 696 & 599 & -13.9 & 66 & 159 & 141 \\
\hline CB95 ... & 860 & 838 & -2.6 & 94 & 117 & 24 \\
\hline $\mathrm{B} 2 \mathrm{C} 26$ & 213 & 209 & -1.9 & 780 & 1,030 & 32 \\
\hline $\mathrm{B} 2 \mathrm{C} 28 \ldots$ & 495 & 477 & -3.6 & 47 & 55 & 17 \\
\hline $\mathrm{B} 2 \mathrm{C} 29 \ldots$ & 542 & 514 & -5.2 & 31 & 32.5 & 5 \\
\hline B2C295_.. & 590 & 571 & -3.2 & 26 & 27 & 4 \\
\hline BC33 & 611 & 538 & -12.0 & 290 & 294 & 1 \\
\hline BC39. & 1,630 & 1,397 & -14.3 & 169 & 216 & 22 \\
\hline BC395 & 2,200 & 1,692 & -23.1 & 65 & 117 & 80 \\
\hline
\end{tabular}

All of the dielectrics containing less than 50 percent of titania and greater than about 30 percent of calcia (fig. 1) decreased in $K$ and $Q$ values after exposure to room conditions for over a year. These changes are probably due to the presence of free lime, which slowly hydrates as a result of exposure to moisture in the air. Specimens in the region of $3 \mathrm{CaO}: \mathrm{TiO}_{2}$ disintegrate after storage for several weeks. The data given in table 1 for these dielectrics were obtained within a day or two after they were matured.

Changes in the dielectric constant due to variations in temperature are given in table 3 . At 1 
$\mathrm{mc} / \mathrm{s}$ these data were obtained by measurements at temperatures given in the table. Equilibrium values of $K$ were not attained for the specimens listed in table 2 for the reason that the temperature at each interval was held constant for only 15 min before measurements were made. For stable specimens, the average values of temperature coefficient of $K$ per degree centigrade are considered to be within $\pm 10 \mathrm{ppm}$, or 5 percent, whichever is greater. All but seven of these stable values are negative and lie within the range of 0 to $-2,250 \mathrm{ppm}$ per degree centigrade. Where no values are given, computations of the coefficient were not made because the coefficient either changed sign or showed large irregularities within this range of temperature. To illustrate the variation of $K$ resulting from changes in temperature and composition, diagrams were constructed for temperatures of $-60^{\circ}, 0^{\circ}$, and $60^{\circ} \mathrm{C}$ (fig. 5). These diagrams exhibit isodielectric-constant lines plotted from the data in table 3 . In contrast to specimens with compositions in the join $\mathrm{SrTiO}_{3}$ $\mathrm{BaTiO}_{3}$ [1], the dielectrics with compositions in the join $\mathrm{CaTiO}_{3}-\mathrm{BaTiO}_{3}$ do not have peak values of $K$ within the temperature range of $-60^{\circ}$ to $85^{\circ} \mathrm{C}$.

TABLE 3. Dielectric constant, at $1 \mathrm{mc} / \mathrm{s}$, from $-60^{\circ}$ to $85^{\circ} \mathrm{C}$, and average temperature coefficient of dielectric constant per ${ }^{\circ} \mathrm{C}$

\begin{tabular}{|c|c|c|c|c|c|c|c|c|c|c|c|c|c|c|c|c|c|}
\hline \multirow{2}{*}{$\begin{array}{c}\text { Specimen } \\
\text { designation }\end{array}$} & \multicolumn{16}{|c|}{ Values of $K$ at- } & \multirow{2}{*}{$\begin{array}{l}\text { A verage } \\
\text { temper- } \\
\text { ature } \\
\text { coeffi- } \\
\text { cient of } \\
K \text { per } \\
{ }_{\mathrm{C}}\end{array}$} \\
\hline & $-60^{\circ} \mathrm{C}$ & $-50^{\circ} \mathrm{C}$ & $-40^{\circ} \mathrm{C}$ & $-30^{\circ} \mathrm{C}$ & $-20^{\circ} \mathrm{C}$ & $-10^{\circ} \mathrm{C}$ & $0^{\circ} \mathrm{C}$ & $10^{\circ} \mathrm{C}$ & $20^{\circ} \mathrm{C}$ & $30^{\circ} \mathrm{C}$ & $40^{\circ} \mathrm{C}$ & $50^{\circ} \mathrm{C}$ & $60^{\circ} \mathrm{C}$ & $70^{\circ} \mathrm{C}$ & $80^{\circ} \mathrm{C}$ & $85^{\circ} \mathrm{C}$ & \\
\hline CT6... & 131 & 129 & 127 & 125 & 123 & 121.5 & 120 & 119 & 117.5 & 116.5 & 115 & 114 & 113 & 112 & 111 & 110.5 & $\begin{array}{l}p p m \\
-1,200\end{array}$ \\
\hline 18BC6.- & 87.8 & 86.8 & 85.9 & 85.1 & 84.4 & 83.7 & 83.0 & 82.4 & 81.7 & 81.0 & 80.4 & 79.9 & 79.4 & 78.8 & 78.3 & 78.0 & $\begin{array}{l}1200 \\
-820\end{array}$ \\
\hline BT18 & 80.5 & 79.7 & 78.9 & 78.3 & 77.6 & 77.0 & 76.5 & 76.0 & 75.4 & 74.8 & 74.3 & 73.8 & 73.4 & 73.0 & 72.7 & 72.5 & -730 \\
\hline $\mathrm{CT}_{2-.}$ & 163.5 & 160 & 157 & 154 & 151 & 148.5 & 146 & 144 & 141.5 & 139.5 & 138 & 136 & 134.5 & 133 & 131.5 & 130.5 & $-1,590$ \\
\hline $6 \mathrm{BC} 2$ & 120 & 118 & 116 & 114 & 112 & 110.5 & 109 & 108 & 106.5 & 105.5 & 104.5 & 103.5 & 102.5 & 102 & 101.5 & 101 & $-1,220$ \\
\hline $6 \mathrm{BC} 5 \ldots$ & 91.7 & 90.4 & 89.2 & 88.1 & 87.1 & 86.2 & 85.6 & 85.0 & 84.4 & 83.8 & 83.2 & 82.5 & 81.8 & 81.1 & 80.4 & 80.1 & -940 \\
\hline $6 \mathrm{BC} 8 \ldots$ & 61.5 & 60.9 & 60.4 & 59. 9 & 59.6 & 59.2 & 58.9 & 58.7 & 58.6 & 58.5 & 58.4 & 58.1 & 57.8 & 57.5 & 57.1 & 57.0 & -530 \\
\hline $6 \mathrm{BC} 9$ & 50.3 & 50.1 & 49.9 & 49. 7 & 49.5 & 49.4 & 49.2 & 49.1 & 48.9 & 48.7 & 48.6 & 48.5 & 48.4 & 48.3 & 48.2 & 48.1 & -310 \\
\hline BT6... & 46.5 & 46.3 & 46.2 & 46.0 & 45.8 & 45.6 & 45.4 & 45.3 & 45.1 & 45.0 & 44. 9 & 44.8 & 44. 7 & 44. 6 & 44.5 & 44.5 & -300 \\
\hline $5 \mathrm{BC} 8$ & 58.6 & 58.2 & 57.7 & 57.3 & 56.9 & 56.6 & 56.3 & 56.0 & 55.8 & 55.5 & 55.2 & 55.0 & 54.7 & 54.5 & 54.3 & 54.2 & -530 \\
\hline $5 \mathrm{BC} 9$ & 50.4 & 50.1 & 49.9 & 49. 7 & 49.5 & 49.4 & 49.2 & 49.1 & 49.0 & 48. 9 & 48. 7 & 48.5 & 48.4 & 48.3 & 48.2 & 48.15 & -320 \\
\hline $5 \mathrm{BC} 95$ & 46.0 & 45.8 & 45.7 & 45.5 & 45.4 & 45.3 & 45. 2 & 45.1 & 45.0 & 44.9 & 44.8 & 44. 7 & 44. 65 & 44. 6 & 44.5 & 44.45 & -230 \\
\hline BT5 & 36.7 & 36.7 & 36.7 & 36.7 & 36.7 & 36.7 & 36.7 & 36.7 & 36.7 & 36.7 & 36.7 & 36.7 & 36.7 & 36.7 & 36.7 & 36.7 & 0 \\
\hline $\mathrm{C} 2 \mathrm{~T} 3$ & 169 & 165.5 & 162 & 158.5 & 156 & 152.5 & 150 & 147.5 & 145.5 & 143.5 & 141.5 & 139.5 & 138 & 136 & 134.5 & 133.5 & $-1,650$ \\
\hline $\mathrm{BC} 22$ & 114 & 112 & 110 & 108 & 106 & 104.5 & 102.8 & 101.5 & 100.2 & 99.4 & 98.1 & 97.0 & 96.0 & 95.0 & 94.0 & 93.4 & $-1,370$ \\
\hline $\mathrm{BC} 24$ & 98.4 & 96.3 & 94.5 & 93.1 & 91.7 & 90.6 & 89.5 & 88.5 & 87.5 & 86.5 & 85.6 & 84.8 & 84.1 & 83.4 & 82.7 & 82.3 & $-1,260$ \\
\hline BC26... & 73.0 & 71.5 & 70.5 & 69.6 & 68.9 & 68.3 & 67.8 & 67.3 & 66.9 & 66.5 & 66.1 & 65.6 & 65.1 & 64.7 & 64.2 & 64.0 & -920 \\
\hline $\mathrm{BC} 27$ & 61.9 & 61.4 & 60.9 & 60.3 & 59.9 & 59.5 & 59.1 & 58.6 & 58.3 & 58.1 & 57.9 & 57.7 & 57.5 & 57.4 & 57.2 & 57.1 & -570 \\
\hline BC28_- & 52.4 & 52.0 & 51.6 & 51. 2 & 51.0 & 50.7 & 50.4 & 50.2 & 50.0 & 49.9 & 49.7 & 49.5 & 49.4 & 49.3 & 49.2 & 49.1 & -460 \\
\hline BC29... & 41.9 & 41.8 & 41.7 & 41.6 & 41. 6 & 41.5 & 41.5 & 41.5 & 41.5 & 41.5 & 41.5 & 41.5 & 41.5 & 41.5 & 41.5 & 41.5 & -70 \\
\hline BT4 & 33.0 & 33.1 & 33.2 & 33.3 & 33.4 & 33.5 & 33.6 & 33.7 & 33.7 & 33.8 & 33.9 & 33.9 & 34.0 & 34.0 & 34.0 & 34.0 & 210 \\
\hline $\mathrm{CT}_{-}$ & 169 & 165 & 161.5 & 158 & 155 & 152 & 149 & 146.5 & 144 & 142 & 139 & 137 & 135 & 133.5 & 132 & 131 & $-1,800$ \\
\hline BC $5 \ldots$ & 106.4 & 104.8 & 103.0 & 101.5 & 99.8 & 98.5 & 97.2 & 96.2 & 95.2 & 94.2 & 93.2 & 92.2 & 91.3 & 90.3 & 89.3 & 88.9 & $-1,240$ \\
\hline BC6 & 80.2 & 79.2 & 78.0 & 77.00 & 76.0 & 75.2 & 74.4 & 73.8 & 73.3 & 72.6 & 72.0 & 71.4 & 70.8 & 70.2 & 69.7 & 69.4 & -980 \\
\hline $\mathrm{BC} 7 \ldots$ & 73.9 & 73.0 & 72.2 & 71.4 & 70.6 & 70.0 & 69.4 & 68.9 & 68.4 & 67.9 & 67.4 & 66.9 & 66.4 & 65.9 & 65.5 & 65.3 & -790 \\
\hline $\mathrm{BC} 8$ & 59.9 & 59.4 & 58.8 & 58.4 & 58.0 & 57.5 & 57.2 & 56.8 & 56.5 & 56.2 & 55.9 & 55.7 & 55.4 & 55.2 & 54.9 & 54.8 & -620 \\
\hline $\mathrm{BC} 9 \ldots$ & 53.4 & 53.1 & 52.8 & 52. 6 & 52.3 & 52.1 & 51.8 & 51. 6 & 51.4 & 51.2 & 51.0 & 50.8 & 50.6 & 50.4 & 50.2 & 50.1 & -440 \\
\hline BT3 & 44.6 & 44.5 & 44.5 & 44. 4 & 44.3 & 44.3 & 44. 2 & 44.1 & 44.1 & 44.0 & 43.9 & 43.9 & 43.8 & 43.8 & 43.7 & 43.7 & -160 \\
\hline $\mathrm{CT}_{\ldots}$ & 169 & 165 & 161.5 & 158 & 155 & 152 & 149 & 146.5 & 144 & 142 & 139 & 137 & 135 & 133.5 & 132 & 131 & $-1,800$ \\
\hline CB1 ......... & 186 & 181 & 176 & 171.5 & 168 & 164.5 & 161.5 & 159 & 156 & 154 & 151.5 & 149.5 & 147 & 145 & 143 & 141.5 & $-1,940$ \\
\hline $\mathrm{CB} 2 \ldots \ldots$ & 237 & 229 & 223 & 216 & 211 & 206 & 201 & 197 & 193 & 189 & 185 & 181 & 178 & 176 & 174 & 173 & $-2,250$ \\
\hline CB3 a $\ldots$ & 254 & 248 & 244 & 238 & 234 & 230 & 227 & 225 & 224 & 225 & 226 & 228 & 231 & 236 & 242 & 250 & - . . \\
\hline CB35 a $\ldots$ & 290 & 282 & 275 & 269 & 264 & 260 & 256 & 253 & 251 & 250 & 250 & 251 & 253 & 257 & 264 & 271 & - \\
\hline $\mathrm{CB} 4{ }^{\mathrm{a}} \ldots$ & 295 & 290 & 285 & 282 & 279 & 276 & 274 & 273 & 275 & 279 & 284 & 291 & 302 & 315 & 331 & 346 & . \\
\hline CB $5{ }^{a} \ldots$ & 349 & 347 & 345 & 343 & 341 & 341 & 339 & 341 & 342 & 348 & 353 & 365 & 378 & 398 & 423 & 444 & - . \\
\hline $\mathrm{CB} 6 \mathrm{a}^{\mathrm{a}} \ldots$ & 409 & 407 & 407 & 406 & 404 & 405 & 406 & 410 & 413 & 427 & 440 & 460 & 483 & 517 & 570 & 604 & ......... \\
\hline CB64 a .... & 410 & 408 & 407 & 407 & 408 & 409 & 412 & 413 & 420 & 435 & 455 & 480 & 515 & 570 & 635 & 690 & ........ \\
\hline CB7 a $\ldots$ & 415 & 420 & 420 & 425 & 430 & 435 & 440 & 445 & 450 & 480 & 510 & 550 & 600 & 660 & 770 & 835 & 4,600 \\
\hline CB8 a & 455 & 470 & 485 & 490 & 515 & 520 & 530 & 540 & 550 & 600 & 660 & 740 & 860 & 1,020 & 1,250 & 1,600 & 7,700 \\
\hline
\end{tabular}

See footnote at end of table. 
TABLE 3. Dielectric constant, at $1 \mathrm{mc} / \mathrm{s}$, from $-60^{\circ}$ to $85^{\circ} \mathrm{C}$, and average temperature coefficient of dielectric constant per ${ }^{\circ} \mathrm{C}$-Continued

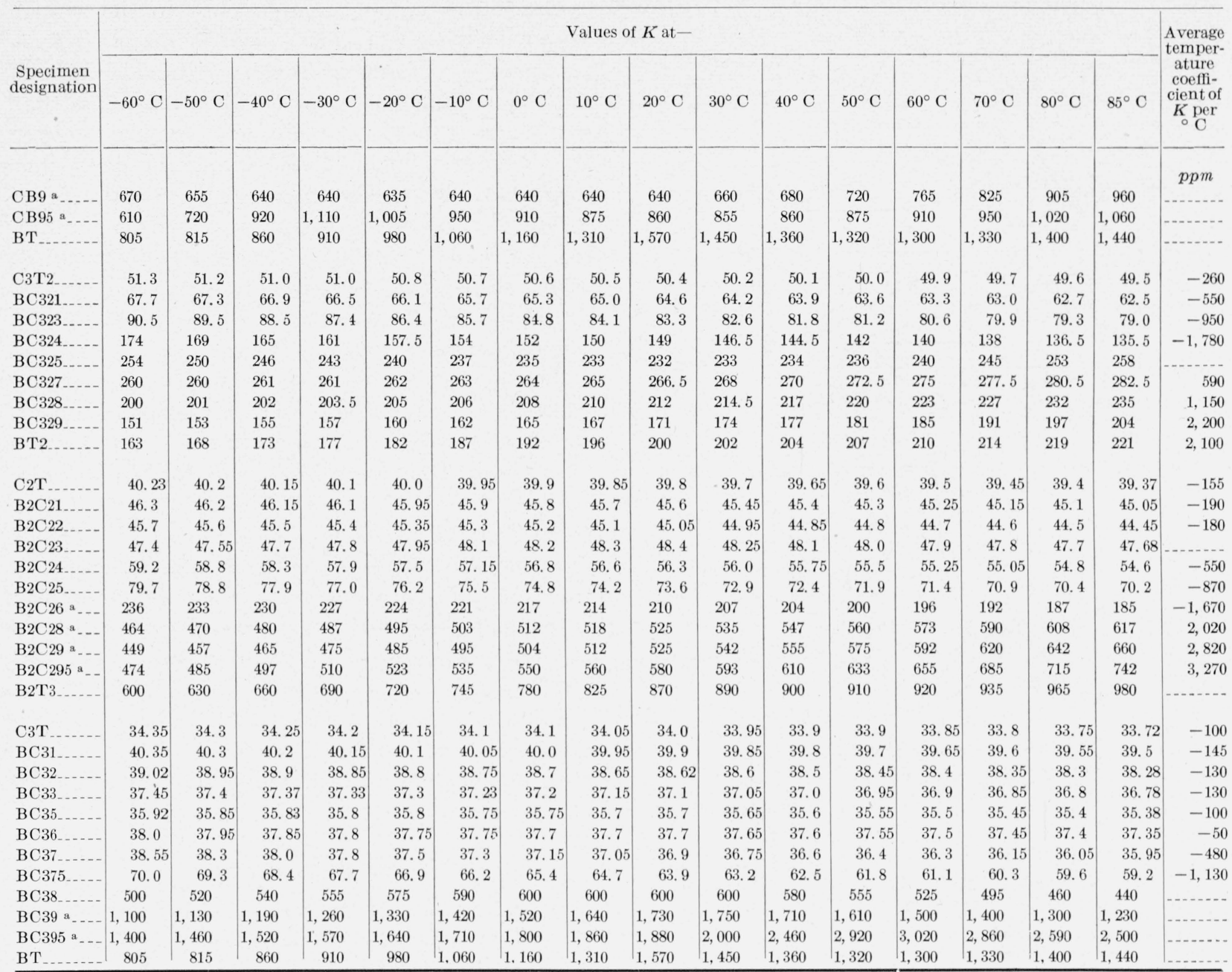

a Values of $K$ depend upon length of time at each temperature.

Greater variation was obtained for the Q values than for the $K$ values. At all frequencies used, dielectrics of high calcia or high titania content had $Q$ values greater than 300 ; those of high baria content had $Q$ values less than 300 . For nearly all of the specimens tested at 3,000 $\mathrm{mc} / \mathrm{s}$, the $Q$ values were lower than those measured at lower frequencies. In general, no great improvement in $K$ or $Q$ was obtained by the use of highest purity titania $(99.9 \%)$ in the preparation of the dielectrics.

Linear thermal expansion was fairly high for all the specimens measured, as shown in table 4 . Since local heating to elevated temperatures cracks all these dielectrics, except in thin sections they should be preheated when solder connections are made directly to the metal electrodes on them.

TABLE 4. Linear thermal expansion

\begin{tabular}{|c|c|c|c|c|c|c|c|}
\hline \multirow{2}{*}{$\begin{array}{c}\text { Specimen } \\
\text { designation }\end{array}$} & \multicolumn{7}{|c|}{ Temperature range from $25^{\circ} \mathrm{C}$ to -} \\
\hline & $100^{\circ} \mathrm{C}$ & $200^{\circ} \mathrm{C}$ & $300^{\circ} \mathrm{C}$ & $400^{\circ} \mathrm{C}$ & $500^{\circ} \mathrm{C}$ & $600^{\circ} \mathrm{C}$ & $700^{\circ} \mathrm{C}$ \\
\hline $\mathrm{C} 2 \mathrm{~T}$ & $\begin{array}{c}\text { Percent } \\
0.07\end{array}$ & $\begin{array}{c}\text { Percent } \\
0.18\end{array}$ & $\begin{array}{c}\text { Percent } \\
0.30\end{array}$ & $\begin{array}{c}\text { Percent } \\
0.42\end{array}$ & $\begin{array}{c}\text { Percent } \\
0.555\end{array}$ & $\begin{array}{c}\text { Percent } \\
0.68\end{array}$ & $\begin{array}{c}\text { Percent } \\
0.82\end{array}$ \\
\hline $\mathrm{CT}$. & .07 & .185 & .31 & .43 & .56 & .69 & .82 \\
\hline $\mathrm{C} 2 \mathrm{~T} 3$ & .07 & .175 & .29 & .405 & .51 & .63 & .75 \\
\hline $\mathrm{CT} 2$ & .065 & .17 & .28 & .39 & .50 & .62 & .735 \\
\hline CT6. & .06 & .15 & .25 & .35 & .45 & .555 & .655 \\
\hline $\mathrm{CB} 5$ & .055 & .16 & .285 & .41 & .545 & .68 & .81 \\
\hline $\mathrm{BC} 26$ & .06 & .155 & .265 & .365 & .475 & .585 & .705 \\
\hline $6 \mathrm{BC} 5$ & .055 & .15 & .255 & .355 & .46 & .57 & .685 \\
\hline $\mathrm{BC} 6 \ldots$ & .065 & .175 & .285 & .40 & .52 & .64 & .765 \\
\hline $\mathrm{B} 2 \mathrm{C} 25$ & .07 & .19 & .325 & .45 & .59 & .725 & .87 \\
\hline BC35 ... & .07 & .18 & .34 & .47 & .605 & .71 & .85 \\
\hline
\end{tabular}



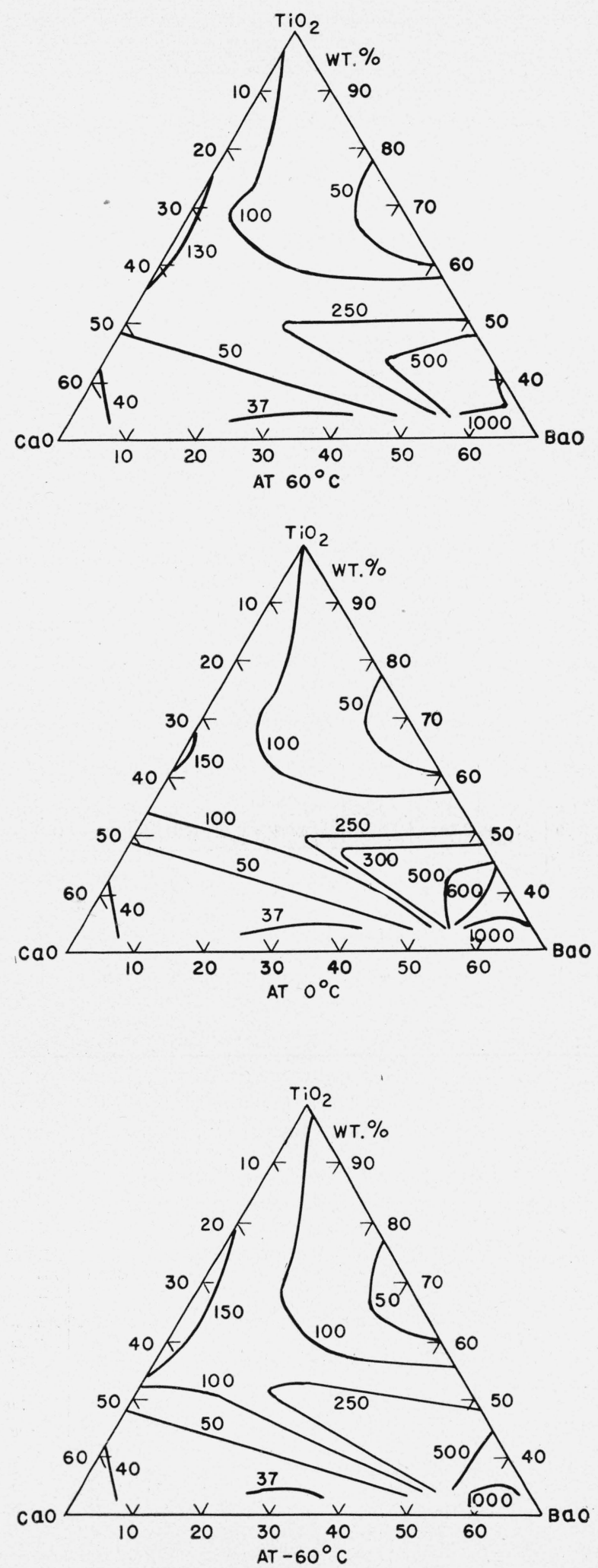

FIgURE 5. Variation in dielectric constant $K$ with composition at $1 \mathrm{mc} / \mathrm{s}$ and at $60^{\circ}, 0^{\circ}$, and $-60^{\circ} \mathrm{C}$.

\section{Summary}

Dielectrics having compositions in the system $3 \mathrm{CaO}: \mathrm{TiO}_{2}-\mathrm{BaTiO}_{3}-\mathrm{TiO}_{2}$ can be prepared from mixtures of titanium dioxide with calcium and barium carbonates. Mature dielectries (less than $0.1 \%$ absorption) were obtained by dry-pressing the calcined mixtures and heating the disks thus formed to various temperatures within the range $1,260^{\circ}$ to $1,500^{\circ} \mathrm{C}$. Matured specimens containing less than 50 percent of titania and greater than about 30 percent of calcia deteriorate in electrical properties after exposure to room conditions for several months.

The dielectric constant, $K$, varies from 34 for $\mathrm{BaO}: 4 \mathrm{TiO}_{2}$ and $3 \mathrm{CaO}: \mathrm{TiO}_{2}$ to several hundred for dielectrics having compositions in the region of barium titanate. Most of the temperature coefficients of $K$ are negative. The $Q$ values range from 20 to 10,000 and are lowest for dielectrics of high baria content. $K$ and $Q$ values of some of the dielectrics are affected by their past thermal history, the $K$ decreasing and the $Q$ increasing for several weeks after these specimens are matured.

Relatively high values of the linear thermal expansion $\left(0.65\right.$ to $0.81 \%$ at $25^{\circ}$ to $\left.700^{\circ} \mathrm{C}\right)$ were obtained for dielectrics having compositions in all regions of the system.

\section{References}

[1] E. N. Bunting, G. R. Shelton, and A. S. Creamer, J. Research NBS 38, 337 (1947) RP1776; J. Am. Ceram. Soc. 30, 4 (1947).

[2] G. R. Shelton, A. S. Creamer, and E. N. Bunting, J. Research NBS 41, 17 (1948) RP1899.

[3] U. S. Pat. 2,394,030 and 2,402,515-8, by E. Wainer. [4] A. von Hippel, et al., Ind. Eng. Chem. 38, 1097 (1946).

Washington, April 3, 1949. 